\title{
El censo de 2018 y sus implicaciones en Colombia
}

El censo nacional de población es un instrumento estadístico esencial en cualquier país. Es un insumo básico para que tanto el sector público como el privado tengan la información pertinente para diseñar sus políticas de la mejor forma y así alcanzar los objetivos propuestos.

En el caso colombiano, el censo ha sido objeto de muchas críticas y objeciones en la medida en que, de acuerdo con las proyecciones poblacionales realizadas por el Departamento Nacional de Estadística (DANE), según el censo de 2005, la población calculada era de 50000000 de personas; sin embargo, el censo de 2018 encontró que somos 45500 000, es decir, una diferencia de $9 \%$.

De acuerdo con los expertos en censos y demografía es normal que la proyección de la población sea mayor al conteo, pero en el caso colombiano la diferencia es muy alta. Juan Daniel Oviedo, director del DANE, lo reconoce al afirmar: "En toda la ronda de 2010 el descache de los relojes poblacionales en América Latina, en promedio, es de $5.7 \%$. Nosotros estamos presentando un descache de $9 \%$ que es importante revisar".

Si se compara la cobertura geográfica del censo del 2005 con el del 2018, se encuentra que en el primero fue del $97 \%$ y en el segundo de $99.8 \%$, lo cual es relevante en la medida que permite tener una imagen más aproximada del tamaño y la composición de la población colombiana y las condiciones habitacionales. Por lo anterior, vale la pena preguntarse: ¿Cuál o cuáles son las razones para que se presente este "descache"? En primer lugar, el censo debió realizarse en 2015, ya que, de acuerdo con los parámetros internacionales, lo ideal sería que el lapso entre uno y otro censo sea de 10 años, a ello se agrega que no se hizo el ajuste anual de las proyecciones ni las correcciones pertinentes en los últimos tres años; en segundo lugar, el acceso de la mujer al mercado laboral que influye en el hecho de que los hogares sean más pequeños y tengan un número menor de hijos; y, en tercer lugar, según Ernesto Morales, exdirector del DANE, el fenómeno de la transición demográfica, que consiste en que a medida que mejora el desarrollo social, disminuye la tasa de natalidad y de mortalidad, y, por consiguiente, la tasa de crecimiento de la población se reduce.

De hecho, según lo manifestó el director del DANE, antes de que se presente la versión definitiva y sea sometida a debate en el Congreso de la República, se nombrará una comisión de expertos del más alto nivel, compuesto por técnicos nacionales y extranjeros del Banco Mundial, de la Comisión Económica para América Latina (CEPAL) y del Banco de Desarrollo de América Latina (CAF), para que revisen los datos recolectados y, de esta forma, se obtenga un documento final del censo que sea lo más verosímil y confiable posible y que las cifras 
obtenidas le den seguridad a los diferentes usuarios para formular las políticas públicas más convenientes.

Desde el punto de vista de las políticas públicas, los datos del censo repercuten en materia económica, social, política y empresarial. En lo económico, al registrarse un menor número de personas, el PIB per cápita ya no será de 6700 dólares sino de 7363 dólares, es decir, un incremento cercano al $10 \%$, que haría ver a los colombianos como "más ricos". Así mismo, si analizamos los datos en términos de consumo per cápita, al ser menor la población real que la proyectada, el consumo registrará un aumento, como también el número de personas que tienen acceso a servicios públicos como energía eléctrica, acueducto y alcantarillado, entre otros.

En lo social, al variar la estructura etaria del país se afectaría la educación colombiana. El director del DANE lo plantea así: la población menor de 25 años en el censo de 2005 era de 20 millones de personas, en el 2018 es de 17 millones, lo cual representa un descenso del 15 $\%$, lo que necesariamente se traduce en que "la política educativa del país podría dejar de preocuparse por la cobertura y, más bien priorizar los recursos hacia la calidad de esa educación". En materia social, lo más preocupante es, tal vez, que de acuerdo con el censo, la población se está envejeciendo, ya que en el censo del 2005 el porcentaje de envejecimiento (porcentaje de adultos mayores por cada 100 jóvenes de 15 años) era de 20,5, en contraste, en el de 2018 fue de 40,6. Lo anterior presionará al Gobierno nacional a buscar la solución adecuada para ofrecer los servicios de salud y de atención, así como garantizar un ingreso mínimo para la manutención de aquellos adultos que no cuenten con una pensión o se encuentren en abandono.

En lo político, cabe recordar que algunos cargos de elección popular como concejales municipales, diputados y representantes a la Cámara, se determinan de acuerdo con la población de las entidades territoriales. Lo mismo sucede con el censo electoral, cuya medición tiene en cuenta el total de la población. Es importante subrayar que si se hubiera realizado el censo en el 2015 o en el 2016, y si sus resultados se hubieran ratificado, la consulta electoral habría sido aprobada.

En lo empresarial, al registrarse un número menor de colombianos censados, los estudios de mercado se basarían en proyecciones distintas, afectando los potenciales demandantes, lo que necesariamente modificaría tanto los niveles de consumo como las decisiones de inversión de las empresas.

En síntesis, el tamaño y la composición de la población de un país resultantes del censo, son importantes tanto para el Gobierno nacional como para el sector privado, porque les permite diseñar sus planes, programas y estrategias de forma más certera, en la medida que disponen de la información necesaria en los ámbitos nacional, departamental y municipal. Se espera que con los ajustes que haga la comisión de expertos, el DANE publique el documento final y lo presente al Congreso para el debate y la aprobación correspondientes, y, por consiguiente, se convierta en ley de la República. Sin embargo, es obvio que los resultados finales van a producir controversia en la Cámara de Representantes, ya que habrá departamentos que ganen influencia política y otros que la pierdan. Es posible que el Congreso de la República no apruebe el censo, como ya lo hizo con los censos de 1995 y de 2005, y así el documento no tendría las repercusiones que hemos reseñado líneas atrás.

Luis E. Vallejo Zamudio

Director Revista Apuntes del Cenes 


\section{The census of 2018 and its implications in Colombia}

The national census of population is an essential statistical instrument in any country . It is a basic input so that both the public and private sectors have the relevant information to design their policies in the best way and thus achieve the proposed objectives.

In the Colombian case, the census has been the object of many criticisms and objections insofar as, according to the population projections made by the National Department of Statistics (DANE, by its acronym in Spanish), according to the 2005 census, the population calculated was 50 million people; however, the 2018 census found that we are 45500000 , that is, a difference of $9 \%$.

According to experts in census and demography it is normal that the projection of the population is bigger than the count, but in the Colombian case the difference is very high. Juan Daniel Oviedo, director of DANE, recognizes when affirming: "In all the round of 2010 the lapse of the population clocks in Latin America, in average, is of 5.7\%. We are presenting a 9\% lapse that it is important to check".

If the geographical coverage of the 2005 census is compared with that of 2018 , it is found that in the first one it was of $97 \%$ and in the second one of $99.8 \%$, which is relevant insofar as it allows having an image more approximate of size and composition of the Colombian population and housing conditions. For the above, it is worth asking: What are the reasons for this lapse? First, the census should have been carried out in 2015 because, according to the international parameters, the ideal is that the period between the two census is 10 years; besides that, neither the adjustment of annual projections nor corrections were made in the last three years; secondly, women's access to the labor market, which influences the fact that households are smaller and have a smaller number of children; and, thirdly, according to Ernesto Morales, former director of DANE, the issue of demographical transition which is that as social development improves, birth and mortality rate diminishes, and therefore, the rate of population growth is reduced.

In fact, as stated by the director of DANE, before the final version is submitted and is under discussion in Congress, a commission of experts of highest level, consisting of national and foreign experts of World Bank, Economic Commission for Latin America and the Caribbean (CEPAL, by its acronym in Spanish) and of the Development Bank of Latin America (CAF) to check the collected data and, thus, a census final document is obtained as credible and reliable as possible and that the obtained figures give security to the different users to formulate the most convenient public policies . 
From the point of view of public policies, census data have an impact on economic, social, political and business matters. In economic terms, when fewer people register, GDP per capita will no longer be $\$ 6700$ but $\$ 7,363$, that is, an increase of close to $10 \%$, which would make Colombians look "richer". Likewise, if we analyze the data in terms of per capita consumption for being less than the actual population the projected one, consumption will record an increase, as well as the number of people who have access to public services such as electricity, water supply and sewerage, among others.

In social terms, by varying the age structure $d$ the country would affect Colombian education. The director of DANE puts it this way: the population under 25 years in the 2005 census was 20 million people, in 2018 is 17 million, which represents a decrease of $15 \%$, which necessarily translates into that "the educational policy of the country could stop worrying about coverage and, rather, prioritize resources towards the quality of that education". In social matters, the most worrisome is, perhaps, that according to the census, the population is getting older, since in the 2005 census the percentage of aging (percentage of older adults for every 100 young people of 15 years) was 20.5 , in contrast, in the 2018 it was 40.6 . This will push the national Government to get the right solution to provide health and care services as well as ensuring a minimum for the maintenance of those adults who do not have a pension or who are homeless.

Politically, it is recalled that some public positions such as Municipal Councilors, Deputies and Representatives are determined according to the population of local entities. The same happens with the electoral census, whose measurement takes into account the total population. It is important to emphasize that if the census had been carried out in 2015 or in 2016, and its results had been ratified, the electoral consultation would have been approved.

In business terms, if there are a smaller number of registered Colombians, the market studies would be based on different projections, affecting the demanders' potential, which would necessarily modify both the consumption levels and the investment decisions of the companies.

In short, the size and composition of the population of a country resulting from the census, are important both for the national Government and the private sector howsoever it allows them to design their plans, programs and strategies in a more accurate way, to the extent they have the necessary information at the national, departmental and municipal levels. It is expected that with the adjustments made by the commission of experts, the DANE will publish the final document and present it to the Congress for debate and the corresponding approval, and, consequently, it will become law of the Republic. However, obviously the final outcome is going to produce controversy in the House of Representatives, since some states will win political influence and others will lose it. It is possible that the Congress of the Republic does not approve the census, as it already did with the censuses of 1995 and 2005, and so the document would not have the repercussions above outlined.

Luis E. Vallejo Zamudio

Director of Apuntes del Cenes Journal 